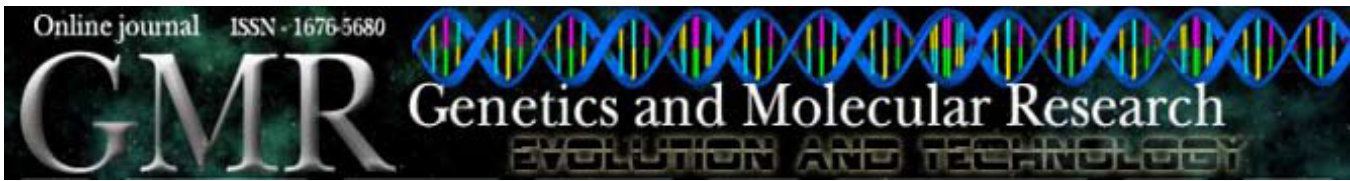

\title{
Mapping of quantitative trait locus associated with maize tolerance to high seed drying temperature
}

\author{
K.C.P.C. Salgado ${ }^{1}$, E.V.R. Von Pinho ${ }^{1}$, C.T. Guimarães ${ }^{2}$, R.G. Von Pinho ${ }^{1}$, \\ C.A. Ferreira ${ }^{1}$ and V. Andrade ${ }^{1}$ \\ ${ }^{1}$ Laboratório de Sementes, Departamento de Agricultura, \\ Universidade Federal de Lavras, Lavras, MG, Brasil \\ ${ }^{2}$ Embrapa Milho e Sorgo, Sete Lagoas, MG, Brasil \\ Corresponding author: E.V.R. Von Pinho \\ E-mail: edila@ufla.br
}

Genet. Mol. Res. 7 (4): 1319-1326 (2008)

Received August 1, 2008

Accepted August 20, 2008

Published November 25, 2008

\begin{abstract}
Quantitative trait locus (QTL) mapping and identification of traits of agronomic importance is important in the process of molecular marker-assisted selection in breeding programs. The molecular map of maize is well saturated and QTL and simple sequence repeat (SSR) markers have been identified, whereas few markers linked to seed quality traits are included. The present study aimed to identify QTL and the gene action and to quantify the effects of these regions in the phenotypic variation related to maize tolerance to high seed drying temperature. SSR markers and 129 segregating families of $\mathrm{F}_{2}$ plants of the cross of intolerant and tolerant lines were used in regression and composite interval mapping methods. Three maize QTL associated with tolerance to high seed drying temperature were identified and mapped to chromosomes 6 and 8, explaining $39 \%$ of the phenotypic variation of the trait with additive, dominance and overdominance gene action. These markers seem to be effectively associated with the evaluated trait, since all were mapped near genes whose expression products were associated with seed desiccation tolerance.
\end{abstract}

Key words: High temperature; Quantitative trait locus; Seeds; Zea mays; Desiccation tolerance 


\section{INTRODUCTION}

Maize seed harvested on the ear favors an earlier harvest and consequently the phases of processing and drying. Moreover, this method allows harvesting shortly before the point of physiological maturity, with maximal seed quality. However, the high moisture content of maize seeds harvested on ears accelerates the deterioration process in view of the high metabolic activity in the period between harvest and drying. The process, besides consuming part of the reserve substances, sets energy and water free, which favors the development of microorganisms and insects. Seeds must therefore be dried quickly after harvest.

According to Magari et al. (1997), to reduce post-harvest production costs, which includes artificial seed drying, maize hybrids that allow a quick reduction of the moisture content of seeds harvested on the ear are needed. However, an exposure of the seeds with high moisture contents to high temperatures during artificial drying can affect seed quality.

In maize, seed susceptibility to damage by high drying temperature is associated with a maternal effect and depends on the genotype (José et al., 2004a). Structural and biochemical traits in seeds have been combined in the acquisition and maintenance of desiccation tolerance (Golovina et al., 2001; Halperin and Koster, 2006). Owing to the large number of elements linked to desiccation tolerance, the control by multiple genes has been associated with this tolerance (Ingram and Bartels, 1996). This process is, however, complex and to date poorly understood, requiring more in-depth studies.

With the advent of the molecular marker technology, new ways of analyzing traits of quantitative inheritance are being developed and, consequently, approaches to quantitative genetics. Molecular markers such as microsatellites enable breeders to map DNA segments containing loci that control these traits, to monitor population segregation and to measure the contributions to the different traits.

Different methods have been proposed for quantitative trait locus (QTL) localization. A marker QTL association can be evaluated by one, two or more markers simultaneously. In the single marker analysis, the distribution of trait values is separately examined for each marker locus. Each test is therefore performed independent of the information of the other loci, thus, this kind of analysis is generally well suited when the objective is merely an identification of marker-linked QTL in detriment of the estimation of position and effects (Silva, 2001). The problem of this type of analysis, according to Liu (1998), is that QTL of small effect and very close to the marker are not distinguished from QTL of great effect, farther away. A more in-depth analysis would be composite interval mapping, where the tests performed in a determined interval do not depend on the effects of other QTL outside this interval, which increases the efficacy of QTL detection.

A large number of genes with a potential effect on thermotolerance as well as on the plant and seed tolerance to water stress have been described; most of the knowledge available on the molecular response to these stresses was compiled in the evaluation of such genes. Besides, the genome regions of the control loci of these traits have become the target of several studies, aimed at the determination of the magnitude of the effects and interactions of these genes or QTL.

The aim of the present study was to identify QTL as well as the gene action and quantification of the effects of these regions on the phenotypic variation in relation to maize tolerance to high seed drying temperature. 


\section{MATERIAL AND METHODS}

The present study was conducted on an experimental area and the seed analysis laboratory of the Agriculture Department, Federal University of Lavras, Lavras, MG, and also in the Núcleo de Biologia Aplicada of Embrapa Milho e Sorgo, Sete Lagoas, MG, in Brazil.

One maize line tolerant to high seed drying temperature was crossed with an intolerant one to obtain the $\mathrm{F}_{2: 3}$ population. An experimental plot of one row of $5 \mathrm{~m}$ with 5 plants $/ \mathrm{m}$ for the lines and $F_{1}$ hybrid was established, along with 8 rows of the same size for the $F_{2}$ generation. The trial was performed in 2 replications, totaling $400 \mathrm{~F}_{2}$ plants and 50 of the other treatments. Each plant was selfed to obtain seeds of the lines and the $\mathrm{F}_{2}$ and $\mathrm{F}_{2: 3}$ generations. Each individual plant was identified in the $\mathrm{F}_{2: 3}$ generation, and leaves were collected and stored at $-80^{\circ} \mathrm{C}$. Seeds were collected when the moisture content was $35 \%$ and dried at $45^{\circ} \mathrm{C}$, in a dryer described by Rosa (2000).

The dry seeds were evaluated for desiccation tolerance by the test of accelerated aging. For the test, the seeds were placed on grids inside the germination boxes divided into mini-chambers. The bottom of each mini-recipient was filled with $40 \mathrm{~mL}$ water, and the "gerboxes" were maintained at $42^{\circ} \mathrm{C}$ for $96 \mathrm{~h}$. After the period in the incubator, the seeds were prepared as described below to germinate.

Four subsamples of 50 seeds were scattered over a moist paper towel holding a water quantity of two and a half times the weight of the dry substratum for germination. The seeds were maintained in the germinator at $25^{\circ} \mathrm{C}$ and evaluated on the fourth and seventh day after sowing. Plantlets with at least two seminal and one main root and a shoot of $2 \mathrm{~cm}$ were considered to be normal.

\section{QTL detection and mapping}

Microsatellite (simple sequence repeat, SSR) trials and marker linkage analyses with 342 initial markers had already been carried out by Salgado (2005). Thirty-four selected SSR markers were chosen for being linked to genes with similar functions and to genes that were expressed differentially in tolerant and intolerant maize to high seed drying temperature, according to Kollipara et al. (2002).

For QTL mapping, the molecular data and percentages of the test of accelerated aging were correlated by the simple regression model, using the software package QTL Cartographer for Windows, version 1.14 (Basten et al., 2000); the associations were considered to be significant at the probability level of $\mathrm{P}<0.01$ and the determination coefficient $\left(\mathrm{r}^{2}\right)$ was interpreted as the estimate of the proportion of phenotypic variance explained by each marker.

Only markers mapped in the linkage groups created by the Gqmol program in an earlier study of Salgado (2005) were considered for composite interval mapping. Markers that were not linked to any group were excluded from this analysis, so that only 39 markers were used in the composite interval analysis. Composite interval mapping (Zeng, 1994) was performed with linkage map information using the QTL Cartographer for Windows program, version 1.14 (Basten et al., 2000). The precision interval was $1 \mathrm{cM}$, with a distance of $10 \mathrm{cM}$ to control the interference of multiple QTL through backward and forward stepwise regression. The most likely QTL localization was estimated by the likelihood function. A curve was plotted in likelihood ratio values for each $\mathrm{cM}$ of the mapped genome. The limit of significance 
was determined by 1000 random permutations of the phenotypic data $(\alpha=0.05)$, according to Doerge and Churchill (1996).

The gene action of each detected QTL was determined by the estimates of the dominance degree (d / [a]) and classified according to the criterion proposed by Stuber et al. (1987): additive = 0 to 0.20 ; partial dominance $=0.21$ to 0.80 ; dominance $=0.81$ to 1.20 , and overdominance $>1.20$.

\section{RESULTS}

Of the markers that were not mapped in the linkage groups, the marker-QTL association was only significant for umc1029 in bin 7.04. The other markers significantly associated with QTL by the analysis of simple linear regression were grouped in the linkage groups used in the composite interval analysis.

Three QTL associated with maize seed tolerance to high drying temperature were mapped by composite interval mapping and the contributions to phenotypic variance, their effects and gene action estimated (Table 1).

Table 1. Position, percentage of phenotypic variance (Vp), effects and gene action of the quantitative trait locus associated with maize tolerance to high seed drying temperature by composite interval mapping and simple regression.

\begin{tabular}{|c|c|c|c|c|c|c|c|c|c|c|c|}
\hline \multirow[t]{3}{*}{ Position } & \multicolumn{7}{|c|}{ Composite interval mapping } & \multirow{2}{*}{\multicolumn{3}{|c|}{ Single marker }} & \multirow[t]{3}{*}{ Gene action } \\
\hline & \multicolumn{3}{|c|}{ LR } & \multirow[t]{2}{*}{$\mathrm{Vp}\left(\mathrm{r}^{2}\right)$} & \multicolumn{3}{|c|}{ Gene effects } & & & & \\
\hline & Marker & Significance & Maximum & & a & d & $(\mathrm{d} / \mathrm{a})$ & $\mathrm{F}$ & Prob. & $\mathrm{Vp}\left(\mathrm{r}^{2}\right)$ & \\
\hline 6.05 & nc0013 & 11.35 & 11.79 & 10.61 & -17.62 & 15.77 & 0.89 & 7.75 & $0.006^{* *}$ & 7.63 & Dominant \\
\hline 6.08 & umc2059 & 8.72 & 10.27 & 10.05 & 17.69 & 4.11 & 0.22 & 10.26 & $0.002 * *$ & 9.97 & Additive \\
\hline 8.05 & phi014 & 8.64 & 9.70 & 14.1 & 12.21 & 23.64 & 1.9 & 6.27 & $0.02 *$ & 5.36 & Overdominant \\
\hline
\end{tabular}

$* * \mathrm{P}<0.01 \%$; $\mathrm{P}<0.05 \%$; LR: likelihood ratio. Significance: limit determined by 1000 random permutations of the phenotypic data for each chromosome. $r^{2}$ : proportion of the phenotypic variance explained by the quantitative trait locus. a: additive effect; $d$ : dominance effect; $d$ / [a]: dominance degree.

In the composite interval analysis, the QTL jointly accounted for $39 \%$ of the phenotypic variation regarding seed tolerance to high drying temperature. Additive, dominance and overdominance effects were detected based on the dominance degree (d / [a]) of the three QTL detected.

No QTL was associated with the 34 selected SSR markers based on the results of Kollipara et al. (2002). In the position 6.05 of chromosome 6, one QTL linked to marker nc013 was identified, which accounted for $10.61 \%$ of the phenotypic variance. This QTL had a dominant effect, and the negative signal of the additive effect indicated that the favorable allele was derived from the parent intolerant to high drying temperature (Table 1). On the same chromosome, but in bin 6.08 linked to marker umc2059, one QTL was identified that explained $10.27 \%$ of the phenotypic variance of the trait, with a dominance effect for phenotype expression. The third QTL was mapped in position 8.05, close to marker phi014. This QTL with an overdominance effect explained $14.10 \%$ of the phenotypic variation.

Based on single marker analysis, the markers nc013 and umc2059 on chromosome 6 explained 7.63 and $9.97 \%$ of the phenotypic variation, respectively, while marker phi014 on chromosome 8 explained $5.36 \%$ of the phenotypic variation of tolerance (Table 1). 
$\mathrm{QTL}_{3}$ in bin 8.05 appeared near three genes (Table 2): $n c r(\operatorname{sod} 3 c)$, which codes for superoxide dismutase, act1, which codes for actin, and $t u b 2$, whose gene product is $\beta$-tubulin (Maize Genetics and Genomics Database, 2005, available at http://www.maizegdb.org/).

\begin{tabular}{|c|c|c|c|c|}
\hline Flanking marker & QTL & Close genes & & Bin \\
\hline \multirow[t]{4}{*}{ nc013, umc2059 } & $\mathrm{QTL}_{1}$ & $d h n 1$ & Dehydrin 1 & 6.05 \\
\hline & $\mathrm{QTL}_{2}$ & $n c r(\operatorname{sod} 3 a)$ & Superoxide dismutase $3 \mathrm{a}$ & 6.05 \\
\hline & & hsp101 & Heat shock protein 101 & 6.06 \\
\hline & & $m \lg 3$ & LEA protein group 3 & 6.07 \\
\hline \multirow[t]{2}{*}{ phi014 } & $\mathrm{QTL}_{3}$ & $t u b 2$ & $\beta$ tubulin 2 & 8.03 \\
\hline & & $n c r(\operatorname{sod} 3 c)$ & Superoxide dismutase $3 \mathrm{c}$ & 8.03 \\
\hline
\end{tabular}

Flanking marker: marker closest to the identified QTL; Close genes: genes in the genome region close to the flanking markers; LEA = late embryogenesis abundant protein; Bin: interval between two fixed markers defined along the chromosomes. Source: Maize Genetics and Genomics Database, 2005, available at http:// www.maizegdb.org/; Close et al., 1999.

The markers nc013 and umc2059, linked to QTL 1 and 2 on chromosome 6, were mapped close to the loci that code for dehydrin 1 ( $(h n 1)$, a heat shock protein $(h s p 101)$ and the LEA (late embryogenesis abundant proteins) protein of group $3(\mathrm{mlg} 3)$, besides the abovementioned superoxide dismutase (Table 2).

\section{DISCUSSION}

The additive, dominance and overdominance effects were determined according to José et al. (2004b), who studied the genetic control of maize seed tolerance to high drying temperature; the additive genetic effects were the most important in the determination of the trait.

In a breeding process where additive allele interaction prevails, selection is easier since the selected individual or group of superior individuals will originate descendants with a superior mean. The dominance or overdominance effect, on the other hand, is favorable for programs of hybrid production, since the combinations of several favorable loci in heterozygosis allow an optimization of genetic gains (Ramalho et al., 1995; Miranda et al., 2005).

Genetic studies of agronomic traits are therefore essential in breeding programs to evaluate the genetic potential of parents to produce enhanced descendents, as well as to increase the efficacy of breeding methods. Information on the magnitude and contribution of additive and dominance gene effects that control the target traits are determinant for the success of any genetic improvement program.

The composite interval mapping and single marker analysis methods were concordant in the identification of the three QTL for maize seed tolerance to high drying temperature. The values of phenotypic variance by single marker analysis were lower than by composite interval analysis, indicating that the latter is more effective at estimating QTL effects.

Several methods have been worked out to increase the detection power and precision of estimates of QTL effect and position. In the present study, all QTL mapped near the markers identified by the composite interval analysis were identified by simple regression analysis as well, demonstrating the consistency of the data and analyses performed, though the estimates were higher in the case of composite interval mapping. 
In this report, the QTL on chromosome 6 were linked to primers selected for being close to the regions of interest, such as primer umc2059, which was selected for being close to primer phi070, which is in turn linked to an LEA protein in bin 6.07.

These markers seem to be effectively associated with the evaluated trait, since all were mapped close to genes whose expression products have been associated with seed desiccation tolerance.

Among the genes near $\mathrm{QTL}_{3}$, tubulin, the main component of cell microtubules, was differentially expressed in tolerant and intolerant maize embryos to high drying temperature (Kollipara et al., 2002). The organization of microtubules is sensitive to different environmental factors, including high temperatures (Bajer et al., 1993). Observations have shown that in embryonic axes of seeds, the organization of microtubules in the root tip cells is maintained in the hydrated state of desiccation-tolerant as well as -intolerant seeds. However, in dehydrated axes of intolerant seeds, the process of seed imbibition does not induce the organization of the cytoskeleton, thus causing damage to the seeds (Berjak and Pammenter, 2003).

Besides the genome region where the $\mathrm{QTL}_{3}$ was mapped, another superoxide dismutase locus, $n \operatorname{cr}(\operatorname{sod} 3 a)$, was found in bin 6.05. Within cells, superoxide dismutase represents the first line of defense against reactive oxygen species (Grene, 2002). The antioxidant mechanisms represent part of the adaptation to heat stress and have been strongly correlated with the acquisition of thermotolerance (Maestri et al., 2002). The increase of free radicals during desiccation explains why genes coding for enzymes linked to reactive oxygen species detoxification, such as superoxide dismutase, have an increased expression in response to desiccation, augmenting seed and plant tolerance to this stress type (Ingram and Bartels, 1996).

Among the genes close to QTL 1 and 2 on chromosome 6, LEA proteins of groups 2 and 3 were mapped. Those of group 2 are also known as dehydrins and are built up under water deficit, low temperatures, increased external osmotic pressure, embryo desiccation, or abscisic acid (ABA) hormone application. These proteins have been associated with maturation and seed desiccation tolerance (Baker et al., 1988; Dure et al., 1989; Yang et al., 1997).

Koag et al. (2003) observed that dehydrins in maize seeds can go through configuration changes at the membrane-water interface, probably for a stabilization of internal membrane structures under stress conditions. The LEA proteins of group 3 are ABA-responsive polypeptides and are built up at the end of maturation, coincident with the beginning of dehydration of maize seeds (Thomann et al., 1992).

Nieto-Soleto et al. (2002) mapped marker umc132 linked to a heat shock protein in maize. Despite the greater occurrence of small heat shock proteins in plants (Mansfield and Key, 1987), Kollipara et al. (2002) found Hsp101 with different expression levels in tolerant and intolerant maize to high seed drying temperature. The protein was found between the loci of the markers nc013 and umc2059, mapped in the present study. According to Gurley (2000), with increased expression of a single protein, Hsp101, the period of heat tolerance in Arabidopsis seeds can be extended to the initial germination stages. In Arabidopsis as well, the coding gene Hsp101 was identified as one of the determinant loci for the capacity of this species to acquire thermotolerance (Hong and Vierling, 2000). A greater synthesis of these proteins could act in the protection of other proteins during the osmotic stress that occurs during cell dehydration at high seed drying temperatures.

The identification of these QTL is certainly a significant contribution to the understanding of maize tolerance to high seed drying temperature, which can lead to the identifica- 
tion of genes and shed light on the mechanisms involved in tolerance expression. Considering that the additive, dominant and overdominant effects are important in the control of tolerance to high drying temperature, the choice of breeding methods that exploit all sources of variability for this trait in maize is of fundamental importance.

\section{ACKNOWLEDGMENTS}

We are grateful to FAPEMIG for the financial support of this study.

\section{REFERENCES}

Bajer AS, Smirnova EA and Mole-Bajer J (1993). Microtubule Converging Centres - Implications for Microtubule Dynamics in Higher Plants. In: Chromosome Segregation and Aneuploidy, NATO ASI Series (Vig BK, ed.). Springer-Verlag, Berlim, 225-239.

Baker J, Steele C and Dure LIII (1988). Sequence and characterization of 6 Lea proteins and their genes from cotton. Plant Mol. Biol. 11: 277-291.

Basten CJ, Weir BS and Zeng ZB (2000). QTL cartographer: version 1.14. North Carolina State University, Raleigh.

Berjak P and Pammenter NW (2003). Orthodox and Recalcitrant Seeds. Chapter 4. In: USDA Forest Service's/Reforestation, Nurseries, and Genetics Resources. Tropical Tree Seed Manual: 137-147.

Close TJ, Choi DW, Campbell SA, Koag MC, et al. (1999). The Dehydrin Multigene Family in Triticeae and Maize. In: Molecular Approaches for the Genetic Improvement of Cereals for Stable Production in Water-Limited Environments. CIMMYT Headquarters, El Batan, Mexico. Available at [http://www.cimmyt.org/ABC/map/research_tools_results/ WSMolecular/WorkshopMolecular/WorkshopMolecularcontents.htm].

Doerge RW and Churchill GA (1996). Permutation tests for multiple loci affecting a quantitative character. Genetics 142: 285-294.

Dure LIII, Crouch M, Harada J, Tuan-Hua DH, et al. (1989). Common amino acid sequence domains among the LEA proteins of higher plants. Plant Mol. Biol. 12: 475-486.

Golovina EA, Hoekstra FA and Van Aelst AC (2001). The competence to acquire cellular desiccation tolerance is independent of seed morphological development. J. Exp. Bot. 52: 1015-1027.

Grene R (2002). Oxidative stress and acclimation mechanisms in plants. Arabidopsis Book 49: 1-20.

Gurley WB (2000). HSP101: a key component for the acquisition of thermotolerance in plants. Plant Cell 12: 457-460.

Halperin SJ and Koster KL (2006). Sugar effects on membrane damage during desiccation of pea embryo protoplasts. $J$. Exp. Bot. 57: 2303-2311.

Hong SW and Vierling E (2000). Mutants of Arabidopsis thaliana defective in the acquisition of tolerance to high temperature stress. Proc. Natl. Acad. Sci. U. S. A. 97: 4392-4397.

Ingram J and Bartels D (1996). The molecular basis of dehydration tolerance in plants. Annu. Rev. Plant Physiol. Plant Mol. Biol. 47: 377-403.

José SCBR, Von Pinho EVR, Von Pinho RG and Silveira CM (2004a). Tolerância de sementes de linhagens de milho a alta temperatura de secagem. Cienc. Agrotecnol. 28: 1107-1114.

José SCBR, Pinho EVRV, Pinho RGV, Ramalho MAP, et al. (2004b). Controle genético da tolerância à alta temperatura de secagem em sementes de milho. Rev. Bras. Milho Sorgo 3: 414-428.

Koag MC, Fenton RD, Wilkens S and Close TJ (2003). The binding of maize DHN1 to lipid vesicles. Gain of structure and lipid specificity. Plant Physiol. 131: 309-316.

Kollipara KP, Saab IN, Wych RD, Lauer MJ, et al. (2002). Expression profiling of reciprocal maize hybrids divergent for cold germination and desiccation tolerance. Plant Physiol. 129: 974-992.

Liu BH (1998). Statistical genomics: linkage, mapping and QTL analysis. CRC Press, Boca Raton.

Maestri E, Klueva N, Perrotta C, Gulli M, et al. (2002). Molecular genetics of heat tolerance and heat shock proteins in cereals. Plant Mol. Biol. 48: 667-681.

Magari R, Kang MS and Zhang Y (1997). Genotype by environment interaction for ear moisture loss rate in corn. Crop Sci. 37: 774-779.

Mansfield MA and Key JL (1987). Synthesis of the low molecular weight heat shock proteins in plants. Plant Physiol. 84: 1007-1017. 
Miranda GV, Souza LV, Guimarães LJ, Melo AV, et al. (2005). Capacidade de combinação de cultivares de milho. Available at [http://www.ufv.br/dft/milho/cbmp01-1.htm]. Accessed March 22, 2005.

Nieto-Sotelo J, Martinez LM, Ponce G, Cassab GI, et al. (2002). Maize HSP101 plays important roles in both induced and basal thermotolerance and primary root growth. Plant Cell 14: 1621-1633.

Ramalho M, Santos JB and Pinto CB (1995). Genética na Agropecuária. Globo, São Paulo; FAEPE, Lavras.

Rosa SDVF (2000). Indução de tolerância à alta temperatura de secagem em sementes de milho por meio de précondicionamento à baixa temperatura. Doctoral thesis, Universidade Federal de Lavras, Lavras.

Salgado KCCP (2005). Mapeamento de QTLs associados à tolerância à alta temperatura de secagem em sementes de milho. Doctoral thesis, Universidade Federal de Lavras, Lavras.

Silva HD (2001). Aspectos biométricos da detecção de QTLs (quantitative trait loci) em espécies cultivadas. Doctoral thesis, Escola Superior de Agricultura "Luiz Queiroz", Piracicaba.

Stuber CW, Edwards MD and Wendell JF (1987). Molecular marker facilitated investigations of quantitative trait loci in maize. II. Factors influencing yield and its component traits. Crop Sci. 27: 639-648.

Thomann EB, Sollinger J, White C and Rivin CJ (1992). Accumulation of group 3 late embryogenesis abundant proteins in Zea mays embryos: roles of abscisic acid and the viviparous-1 gene product. Plant Physiol. 99: 607-614.

Yang H, Saitou T, Komeda Y, Harada H, et al. (1997). Arabidopsis thaliana ECP63 encoding a LEA protein is located in chromosome 4. Gene 184: 83-88.

Zeng ZB (1994). Precision mapping of quantitative trait loci. Genetics 136: 1457-1468. 